\title{
Mobile fishing gear reduces benthic megafaunal production on Georges Bank
}

\author{
Jerome M. Hermsen ${ }^{1,3, *}$, Jeremy S. Collie ${ }^{1}$, Page C. Valentine ${ }^{2}$ \\ ${ }^{1}$ University of Rhode Island, Graduate School of Oceanography, Narragansett, Rhode Island 02882, USA \\ ${ }^{2}$ US Geological Survey, 384 Woods Hole Road, Woods Hole, Massachusetts 02543, USA \\ ${ }^{3}$ Present address: Fishery Statistics Office, Northeast Regional Office, National Marine Fisheries Sevice, \\ 1 Blackburn Drive, Gloucester, Massachusetts 01930, USA
}

\begin{abstract}
This study addresses the effect of mobile fishing gear disturbance on benthic megafaunal production on the gravel pavement of northern Georges Bank. From 1994 to 2000, we sampled benthic megafauna with a $1 \mathrm{~m}$ Naturalists' dredge at shallow ( 47 to $62 \mathrm{~m}$ ) and deep ( 80 to $90 \mathrm{~m}$ ) sites. The cessation of fishing in large areas of Georges Bank in January 1995 allowed us to monitor changes in production at a previously disturbed site. Production at a shallow disturbed site varied little over the sampling period ( 32 to $57 \mathrm{kcal} \mathrm{m}^{-2} \mathrm{yr}^{-1}$ ) and was markedly lower than production at the nearby recovering site, where production increased from $17 \mathrm{kcal} \mathrm{m}^{-2} \mathrm{yr}^{-1}$ in 1994 before the closure to $215 \mathrm{kcal} \mathrm{m}^{-2} \mathrm{yr}^{-1}$ in 2000. Atlantic sea scallops Placopecten magellanicus and green sea urchins Strongylocentrotus droebachiensis dominated production at the recovering site. The community production:biomass ratio decreased over time at the recovering site as the sea scallop population matured. At the deep sites, production remained significantly higher at undisturbed sites (174 to $256 \mathrm{kcal} \mathrm{m}^{-2} \mathrm{yr}^{-1}$ ) than at disturbed sites (30 to $52 \mathrm{kcal} \mathrm{m}^{-2} \mathrm{yr}^{-1}$ ). The soft-bodied tube-building polychaete Thelepus cincinnatus dominated production at the undisturbed site, while hard-shelled bivalve molluscs Astarte spp. and P. magellanicus were prevalent at the disturbed site. Mobile fishing gear disturbance has a conspicuous effect on benthic megafaunal production in this hard-bottom habitat. Cessation of mobile fishing has resulted in a marked increase in benthic megafaunal production. These findings should help fishery managers to gauge the costs and benefits of management tools such as area closures and low-impact fishing gears.
\end{abstract}

KEY WORDS: Benthic communities - Benthic production - Fishing impacts · Habitat disturbance · Scallop dredging

Resale or republication not permitted without written consent of the publisher

\section{INTRODUCTION}

Concern over the ecosystem effects of fishing has led several countries to close parts of the sea bottom to mobile fishing gear for the purpose of preserving ecosystem function and/or fish production (Bradstock \& Gordon 1983, Jennings 2000, McClanahan \& Arthur 2001, Roberts et al. 2001). Off the NE coast of the United States, approximately $10000 \mathrm{~km}^{2}$ of sea bottom in 2 areas on Georges Bank have been closed to all bottom-fishing towed gear in an effort to protect commercially valuable fish stocks (Murawski et al. 2000). Georges Bank, a large submarine plateau on the conti- nental shelf off the coast of New England, has historically supported large harvests of commercially valuable groundfish (e.g. Atlantic cod Gadus morhua and haddock Melanogrammus aeglefinus) and Atlantic sea scallops Placopecten magellanicus. Swathes of gravel pavement, deposited during the last glacial retreat approximately $15000 \mathrm{yr}$ ago, cover large portions of the NE edge of the Bank and are particularly important biologically. This pavement is known to be a spawning ground for Atlantic herring Clupea harengus and is an important nursery habitat for juvenile Atlantic cod and haddock (Lough et al. 1989, Valentine \& Lough 1991). The gravel pavement supports a diverse array of errant 
and attached fauna that can harbor prey or shelter juvenile demersal groundfish (Collie et al. 1997).

In the past $40 \mathrm{yr}$, Georges Bank has been subjected to heavy fishing pressure from American, Canadian and distant-water fleets (Fogarty \& Murawski 1998). This pressure has led to dramatic declines in the abundance of several target species. The decline of principal groundfish and flounder (e.g. yellowtail flounder Limanda ferruginea) resources on Georges Bank has fueled concern over the degradation of habitat associated with the mobile, bottom-fishing towed gear of the scallop and trawl fisheries (Langton et al. 1996). In January 1995, 2 areas of Georges Bank were closed to mobile fishing gear (creating 2 of the largest such areas in the world) to curb fishing pressure on commercially valuable cod and haddock stocks.

Recent experiments and directed sampling have provided valuable insight into both the short- and longterm effects of bottom fishing (for reviews see Auster \& Langton 1999 and Kaiser et al. 2002). Chronic disturbance by trawls and dredges reduces benthic megafaunal abundance, biomass and diversity (Collie et al. 2000). Disturbance by bottom-fishing towed gear also reduces habitat heterogeneity by smoothing out bedforms and removing habitat-forming species (Auster \& Langton 1999). Experimental trawling in the Irish Sea reduced the density of some sessile fauna (Alcyonium digitatum and hydroids) by $50 \%$ (Kaiser \& Spencer 1996). Not as well understood, however, is the effect these perturbations have on the productivity of these ecosystems.

Investigation into the role of anthropogenic disturbance on benthic production is important for several reasons, foremost being the role of the benthos in the transfer of energy to higher trophic levels. The diets of several commercially important demersal fish are dominated by benthic invertebrates (Steimle 1987, Bowman et al. 2000). On Georges Bank, molluscs and crustaceans constitute a significant portion of the diet of Atlantic cod (Bowman et al. 2000). Georges Bank haddock have a diet similarly dominated by crustaceans and echinoderms (Bowman et al. 2000).

Two ways that investigators can assess production of benthic fauna are (1) directly, by estimating direct loss of biomass from a population (e.g. Collie 1985), or (2) indirectly, through the use of an allometric relationship to calculate a production-to-biomass (P:B) ratio (e.g. Wildish \& Peer 1983) or by applying P:B ratios from other studies (Robertson 1979, Crisp 1984, Steimle 1987, Brey 2001). The production of 3 amphipod species from Georges Bank has been estimated directly with cohort-based methods (Collie 1985). When cohorts are not easily distinguishable from length-frequency histograms, the size-frequency (Hynes) method has been used (e.g. Collie 1987). This method calculates production by summing the biomass lost between size classes (Krueger \& Martin 1980). Using P:B values from the literature for some taxa and reasonable estimates to fill in gaps for less well-studied groups, Steimle (1987) estimated benthic secondary production on Georges Bank. Benthic secondary production on this particularly productive part of the continental shelf was estimated to be higher than for most other shelf and coastal areas (Steimle 1987).

One might expect that a degree of trawling would enhance benthic megafaunal productivity, as opportunistic species would most likely be favored in a moderately disturbed environment (Dayton \& Hessler 1972, Jennings et al. 2001, 2002). Smaller-bodied animals with high intrinsic rates of increase may benefit from the reduction in biomass of larger-bodied benthic fauna through a reduction in competition (Jennings et al. 2002). However, there is likely a threshold beyond which chronic disturbance adversely affects productivity. In one of the few studies of the effects of disturbance on benthic production, a meta-analysis of 201 data sets, Emerson (1989) found that productivity was negatively correlated with wind stress and elevated bottom current speeds. The potential effects of anthropogenic disturbance, such as bottom-fishing towed gear, on the production of invertebrate prey of commercially important fish are just beginning to be understood.

To date, only 1 other study has examined the effects of mobile fishing gear disturbance on benthic production. Jennings et al. (2001) compared production at 2 sites in the North Sea that each experience a range of beam-trawl disturbance. An allometric relationship, based upon a suite of variables, was used to estimate community production. Although beam trawling raised community $\mathrm{P}: \mathrm{B}$ in disturbed areas by favoring smaller species, overall productivity in the most disturbed areas was significantly lower because of a decrease in benthic biomass (Jennings et al. 2001).

The purpose of this study was to estimate the effects of bottom fishing on benthic production on the NE part of Georges Bank. We used direct methods to estimate production for the most abundant species, and P:B ratios for the remaining species. This is the first study to investigate the effects of mobile fishing gear disturbance using direct estimates of community production.

\section{MATERIALS AND METHODS}

Study sites. Study sites on the northern part of Georges Bank were chosen in an effort to compare areas with different levels of disturbance by bottomfishing towed gear while accounting for natural variation in community composition with depth and sedi- 
ment type. Disturbance level was determined with sidescan sonar surveys and with scallop fishing effort data up to 1993. In order to account for community changes associated with depth, sites ranging from 47 to $62 \mathrm{~m}$ in water depth were classified as 'shallow' and sites ranging from 80 to $90 \mathrm{~m}$ in depth were classified as 'deep'. Sidescan sonar imagery was used to select only those sites with a gravel substratum. Effort data collected since 1994 have served to confirm our disturbance-level designations at the deep sites (J. Black, Canada Department of Fisheries and Oceans, pers. comm.)

Over the course of the $7 \mathrm{yr}$ study, 9 sites were sampled (Fig. 1, Table 1). In January 1995 a large portion of Georges Bank was closed to all bottom-fishing towed gear. The designation of Sites 17 and 18 was changed to reflect the concomitant diversions in fishing effort that took place after the closure. In 1997, Site 17W was added to the study to serve as an additional fished control site for recovering Site 17. Both otter-trawl and scallop fishing effort data collected since 1994 confirm our designations of Site 17 as an unfished, recovering site and of Sites 17W and 18 as control sites (Rago \& McSherry 2002, D. Stevenson, National Marine Fisheries Service, pers. comm.).

Sampling of the benthic invertebrate community. Benthic megafauna, which we operationally define as ani-

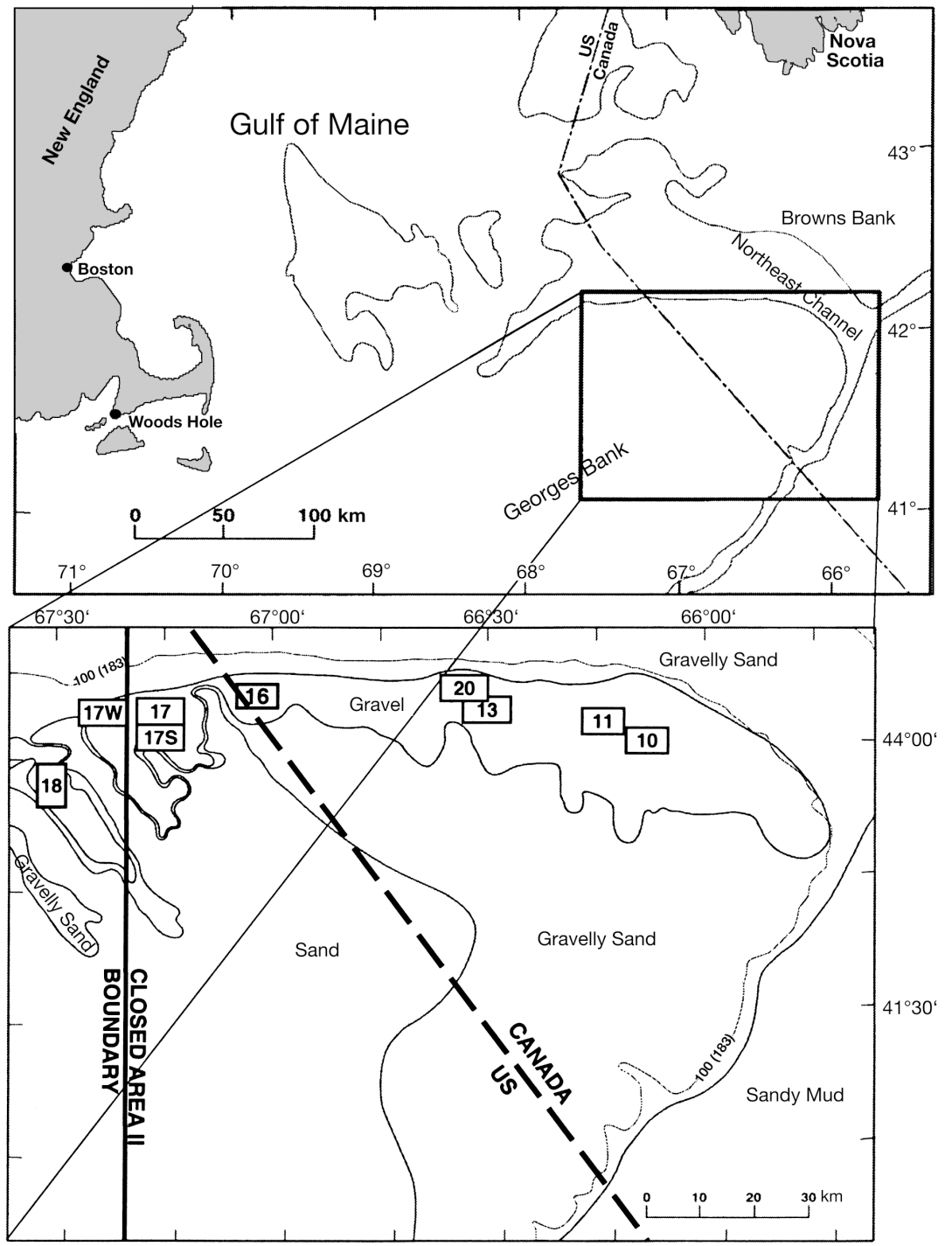

Fig. 1. Map of sampling sites on the northern part of Georges Bank. Depth contour on the lower map denotes 100 fathoms (183 m)

Table 1. List of cruises, sampling sites, depth, and disturbance levels for this study. 0 designates undisturbed stations; $x$ designates disturbed stations

\begin{tabular}{|c|c|c|c|c|c|c|c|c|c|}
\hline Site & Depth (m) & April 1994 & November 1994 & July 1995 & May 1996 & July 1997 & August 1998 & June 1999 & November 2000 \\
\hline 16 & Shallow (62) & & & & $x$ & & & & \\
\hline $17 \mathrm{~W}$ & Shallow (50) & & & & & $x$ & $x$ & $x$ & \\
\hline $17^{\mathrm{a}}$ & Shallow (47) & $x$ & $x$ & 0 & 0 & 0 & 0 & 0 & 0 \\
\hline $18^{\mathrm{a}}$ & Shallow (48) & 0 & 0 & $x$ & $x$ & $x$ & $x$ & $x$ & $x$ \\
\hline $17 \mathrm{~S}$ & Shallow (50) & & & & & 0 & & 0 & \\
\hline 13 & Deep (80) & $x$ & $x$ & & & $x$ & $x$ & $x$ & \\
\hline 10 & Deep (90) & 0 & 0 & & & & & & \\
\hline 11 & Deep (85) & & 0 & & & & & & \\
\hline 20 & Deep (85) & & 0 & & & 0 & 0 & 0 & \\
\hline
\end{tabular}


mals $>5 \mathrm{~mm}$, were sampled with a $1 \mathrm{~m}$ wide Naturalists' dredge fitted with a $6.4 \mathrm{~mm}$ mesh liner. Tow duration was short ( $\sim 30 \mathrm{~s})$ to avoid overfilling the net bag and losing the sample. We aimed for 3 replicate samples per station. Samples were brought aboard and emptied onto plywood on the deck of the vessel. Animals were then manually removed from the sediment and sample sediment volume recorded. To account for any fauna overlooked in the first sorting, a 91 subsample was sieved through a $5 \mathrm{~mm}$ mesh screen. Mean subsample size throughout the study was approximately $9 \%$ of the total sample volume. The contents of the subsample were later scaled to the volume of the entire sample. All animals were preserved in $10 \%$ formalin/seawater solution buffered with boric acid.

To convert volume (l) of sediment to area sampled $\left(\mathrm{m}^{2}\right)$ by the Naturalists' dredge, we assumed the $100 \mathrm{~cm}$ wide dredge sampled uniformly to a depth of $2 \mathrm{~cm}$. Every liter of sediment sampled was then equivalent to $0.05 \mathrm{~m}^{2}$ of the sea bottom. Because we chose to sample in areas with a continuous veneer of gravel, this assumption of uniform dredge efficiency was probably not violated. Even though the dredge certainly sampled with less than $100 \%$ efficiency, biomass and production estimates between sites sampled during the course of this study could still be compared.
In the laboratory, organisms were identified to the lowest taxonomic level possible, counted and weighed after blotting with a paper towel. Because weight loss due to preservation is highly variable across species, we did not account for weight changes due to preservation in the blotted wet weights. The species list was filtered to keep only those species that were sampled quantitatively with the dredge. Individuals from 20 of the most abundant species were measured with vernier calipers to the nearest $\mathrm{mm}$ (Table 2). At least 30 individuals of each of these 20 species were also measured and weighed to generate length-weight relationships with the equation $W=a L^{b}$, where $W$ is weight $(\mathrm{g})$ and $L$ is the length $(\mathrm{mm})$ of the measured body part or structure. The log-transformation of this equation, $\log (W)=\log (a)+b \log (L)$, was fitted with standard linear regression.

Direct estimates of production. If there were more than 30 individuals of a species in a sample, length-frequency distributions were compiled and production was calculated with the size-frequency (Hynes) method. This method depends upon several assumptions including: (1) that the species is univoltine, or that generation time is known; (2) that all individuals can potentially grow to the maximum size class; (3) that growth in length is linear and is constant through time; and (4) that lifespan is known. To deter-

Table 2. List of the 20 species measured for which production was estimated with the size-frequency method. Also listed are the body part or structure used for the measurement, number of animals measured, $a$ and $b$ coefficients of the derived length-weight relationship, the $\mathrm{r}^{2}$ of the standard linear regression, and the maximum lifespan and corresponding reference

\begin{tabular}{|c|c|c|c|c|c|c|c|}
\hline Species & Measurement & $\mathrm{n}$ & a & $b$ & $\mathrm{r}^{2}$ & $\begin{array}{l}\text { Life span } \\
\quad(y r)\end{array}$ & Source \\
\hline Astarte borealis & Maximum shell height & 114 & $3.4 \times 10^{-4}$ & 3.047 & 0.99 & 5.0 & Wildish \& Peer (1983) \\
\hline Astarte elliptica & Maximum shell height & 70 & $2.9 \times 10^{-4}$ & 3.099 & 0.98 & 5.0 & Wildish \& Peer (1983) ${ }^{\mathrm{a}}$ \\
\hline Astarte montagui & Maximum shell height & 80 & $4.0 \times 10^{-4}$ & 2.957 & 0.99 & 5.0 & Wildish \& Peer (1983) ${ }^{\mathrm{a}}$ \\
\hline Astarte subaequilatera & Maximum shell height & 36 & $2.3 \times 10^{-3}$ & 2.521 & 0.76 & 5.0 & Wildish \& Peer (1983) \\
\hline Astarte undata & Maximum shell height & 56 & $1.6 \times 10^{-3}$ & 2.615 & 0.90 & 5.0 & Wildish \& Peer $(1983)^{\mathrm{a}}$ \\
\hline Asterias vulgaris & Center of mouth to tip of arm & 49 & $2.2 \times 10^{-3}$ & 2.126 & 0.94 & 10.0 & Wildish \& Peer (1983) \\
\hline Buccinum undatum & Shell height & 56 & $1.3 \times 10^{-4}$ & 2.925 & 0.99 & 15.0 & $\begin{array}{l}\text { Giguère \& Brulotte } \\
(2000)\end{array}$ \\
\hline Cancer irroratus & Carapace width & 87 & $1.7 \times 10^{-4}$ & 2.904 & 0.98 & 7.5 & Bigford (1979) \\
\hline Crangon septemspinosa & Base of eyestalk to tip of telson & 60 & $3.4 \times 10^{-6}$ & 3.249 & 0.84 & 2.5 & Haefner (1979) \\
\hline Cyclocardia borealis & Maximum shell height & 44 & $4.5 \times 10^{-4}$ & 2.973 & 0.98 & 5.0 & Wildish \& Peer (1983) \\
\hline $\begin{array}{l}\text { Dichelopandalus } \\
\text { leptocerus }\end{array}$ & Base of eyestalk to tip of telson & 51 & $6.3 \times 10^{-6}$ & 3.049 & 0.93 & 4.0 & Williams (1984) \\
\hline Eualus pusiolus & Base of eyestalk to tip of telson & 58 & $1.6 \times 10^{-5}$ & 2.998 & 0.89 & 5.0 & Wildish \& Peer (1983) \\
\hline Hyas coarctatus & Carapace length & 61 & $7.6 \times 10^{-5}$ & 3.173 & 0.95 & 4.0 & Hartnoll $(1963,1965)$ \\
\hline Ophiopholis aculeata & Disc diameter & 96 & $7.2 \times 10^{-4}$ & 2.932 & 0.92 & 5.0 & Wildish \& Peer (1983) \\
\hline Pagurus acadianus & Cephalothorax & 38 & $4.3 \times 10^{-4}$ & 3.244 & 0.95 & 5.0 & Wildish \& Peer (1983) \\
\hline Pagurus pubescens & Cephalothorax & 48 & $3.4 \times 10^{-4}$ & 3.449 & 0.94 & 10.0 & Wildish \& Peer (1983) \\
\hline Pandalus montagui & Cephalothorax & 49 & $3.6 \times 10^{-5}$ & 3.079 & 0.97 & 4.0 & Williams (1984) \\
\hline Placopecten magellanicus & Maximum shell height & 44 & $7.7 \times 10^{-5}$ & 3.078 & 0.97 & 20.0 & Wildish \& Peer (1983) \\
\hline Spirontocaris liljeborgii & Base of eyestalk to tip of telson & 69 & $4.9 \times 10^{-6}$ & 3.398 & 0.89 & 2.5 & Williams (1984) \\
\hline $\begin{array}{l}\text { Strongylocentrotus } \\
\text { droebachiensis }\end{array}$ & Diameter & 64 & $1.4 \times 10^{-3}$ & 2.584 & 0.94 & 10.0 & Wildish \& Peer (1983) \\
\hline
\end{tabular}


mine annual production, we used the equation of Krueger \& Martin (1980):

$$
P_{i}=\frac{S_{i}}{\mathrm{MA}_{i}}\left[\sum_{j=1}^{S-1}\left(N_{i, j}-N_{i, j+1}\right)\left(W_{i, j} W_{i, j+1}\right)^{0.5}+N_{i, S} W_{i, S}\right]
$$

where $P$ is the annual production of species $i, S$ is the number of size classes used in the analysis of species $i$, MA is the maximum age of species $i, N_{i, j}$ is the number of individuals of species $i$ in size category $j$, and $\left(W_{i, j} W_{i, j+1}\right)^{0.5}$ is the geometric mean weight between 2 size classes of species $i$. Krueger \& Martin (1980) have indicated that when mass growth is exponential, the geometric mean weight between size classes is a more accurate estimate of average weight than the arithmetic mean. If the number of animals measured at a station did not equal the number of animals captured there (i.e. a subsample was measured or animals were too damaged to measure), the length-frequency distribution was scaled to match the total number of animals caught. In the rare instance that a replicate from a site and year was not measured, the length-frequency was calculated from the mean proportion of animals in each size category from replicates that were measured at that site and year. In 1994, 4 sites were sampled twice, in April and November. For that year, the number in each length category was averaged over the sampling dates. Also for 1994 only, if the number of animals per sampling date averaged $<20$, we used indirect methods to calculate production.

For 1 species, Placopecten magellanicus, it was possible to track cohorts through time at Site 17. The NORMSEP program (Hasselblad 1966) was used to identify cohorts in the length-frequency distributions, which were aggregated at $5 \mathrm{~mm}$ intervals of shell height. For this species and site only, we used the increment-summation (Crisp 1984) method to estimate production. Production of each scallop cohort, $P_{C}$ is

$$
P_{C}=\sum_{t} \frac{N_{t}+N_{t+1}}{2}\left(\bar{W}_{t+1}-\bar{W}_{t}\right)
$$

where $N_{t}$ is number of scallops in the cohort estimated at time $t$. The corresponding mean weight of the cohort, $\bar{W}_{\mathrm{t}}$, was calculated from the length-weight relationship (Table 2), adjusted for the standard deviation of the length distribution (Pienaar \& Ricker 1968). Total production was summed over scallop cohorts and expressed on a calendar-year basis for comparison with the size-frequency method.

Indirect estimates of production. For samples at a site in a given year with insufficient numbers (i.e. $<30$ ) to create a length-frequency distribution, and for 19 additional species that made up the bulk of the total biomass of all animals collected over the course of the study, production was calculated with either a P:B ratio from the literature when available, or with $\mathrm{P}: \mathrm{B}$ ratios calculated using the allometric relationship of Brey (2001). Brey's (2001) empirical model is a multiple linear regression with 11 parameters including mean energy content of the organism $(\mathrm{kJ})$, depth $(\mathrm{m})$, temperature $\left({ }^{\circ} \mathrm{C}\right)$, whether the organism was motile, and whether the organism belonged to the phyla echinodermata or mollusca. We used the taxa-specific conversion factors provided by Brey (2001) to convert wet mass to ash-free dry mass (AFDM) and AFDM to joules. For each species and site, the production:biomass ratio was calculated using the mean depth $(\mathrm{m})$ and the mean individual body mass $(\mathrm{kJ})$ of the species from that site and year. We used $9^{\circ} \mathrm{C}$ as the mean bottom temperature for all of the P:B ratio estimates (D. Mountain, National Marine Fisheries Service, pers. comm.).

Direct and indirect estimates of production for the 39 species were then summed to generate an estimate of benthic production in $\mathrm{g} w \mathrm{w} \mathrm{m} \mathrm{m}^{-2} \mathrm{yr}^{-1}$ for each site and year. Krueger \& Martin (1980) gave an equation for the variance of a production estimate for a single species, but there is no corresponding equation for the variance of the sum of production estimates of potentially covarying species. We also calculated the production at each site in each year in $\mathrm{kcal} \mathrm{m}^{-2} \mathrm{yr}^{-1}$. Community P:B ratios were calculated by dividing the sum of the biomass by the sum of the production from the 2 methods for the 39 species for each site and year.

A paired $t$-test was performed on the untransformed annual production data ( $\mathrm{kcal} \mathrm{m}^{-2} \mathrm{yr}^{-1}$ ) from the deep sites after testing for homogeneity of variances with a 2-tailed $F$-test. We did not perform a similar test on the annual production data from the shallow sites because such a test would not have been meaningful due to changes in the disturbance pattern at these sites associated with the closure of Site 17 in early 1995.

\section{RESULTS}

The 39 species for which we estimated production in this study accounted for over $99 \%$ of the biomass of the total of 124 species sampled quantitatively by the Naturalists' dredge. Our direct estimates of production, based on 37000 individual measurements, accounted for $73 \%$ of the total biomass of these 39 species over the 7 yr study.

The sites sampled on northern Georges Bank over the course of this study fall into 2 main groups: a shallow group on the US side of the Hague Line and a deep group in the Canadian exclusive economic zone (Fig. 1, Table 1). Although we were not able to sample all depth and disturbance levels in all years, we were able to obtain enough samples to compare disturbed, 
Table 3. List of additional 19 species, and their corresponding $\mathrm{P}: \mathrm{B}$ ratio if available from the literature, for which production was estimated by multiplying mean biomass at a site and year by the P:B (production:biomass) ratio

\begin{tabular}{|c|c|c|}
\hline Species & P:B ratio & Source \\
\hline Aphrodita hastata & $1.9^{\mathrm{a}}$ & $\begin{array}{l}\text { George \& } \\
\text { Warwick (1985) }\end{array}$ \\
\hline Astarte castanea & $0.4-0.6$ & Brey (2001) \\
\hline Chlamys islandicus & $0.1-1.1$ & Brey (2001) \\
\hline Colus pubescens & $0.4-0.9$ & Brey (2001) \\
\hline Colus stimpsoni & $0.3-0.5$ & Brey (2001) \\
\hline Crossaster papposus & $0.2-0.7$ & Brey (2001) \\
\hline Cucumaria frondosa & $0.1-0.5$ & Brey (2001) \\
\hline Echinarachnius parma & 0.7 & Brey (2001) \\
\hline Euspira heros & $0.6-1.1$ & Brey (2001) \\
\hline Henricia sanguinolenta & $0.3-0.6$ & Brey (2001) \\
\hline Lebbeus groenlandicus & $0.9-1.8$ & Brey (2001) \\
\hline Modiolus modiolus & 0.5 & $\begin{array}{l}\text { George \& } \\
\text { Warwick (1985) }\end{array}$ \\
\hline Musculus discors & $0.6-1.6$ & Brey (2001) \\
\hline Mytilus edulis & 2.2 & $\begin{array}{l}\text { Howe \& } \\
\text { Leatham (1984) }\end{array}$ \\
\hline Neptunea decemcostata & $0.3-0.5$ & Brey (2001) \\
\hline Nereis zonata & $2.6^{\mathrm{b}}$ & Kristensen (1984) \\
\hline Pagurus arcuatus & $0.5-1.7$ & Brey (2001) \\
\hline Thelepus cincinnatus & $0.9-3.0$ & Brey (2001) \\
\hline Urticina felina & $0.3-1.1$ & Brey (2001) \\
\hline $\begin{array}{l}{ }^{a} \text { Mean for Aphroditidae } \\
{ }^{b} \text { Mean of } 2 \text { congeners }\end{array}$ & & \\
\hline
\end{tabular}

undisturbed, and recovering areas while accounting for differences in community composition with depth in most years (Table 1).

Production was estimated directly for 20 species when the sample size at a site and year was sufficient

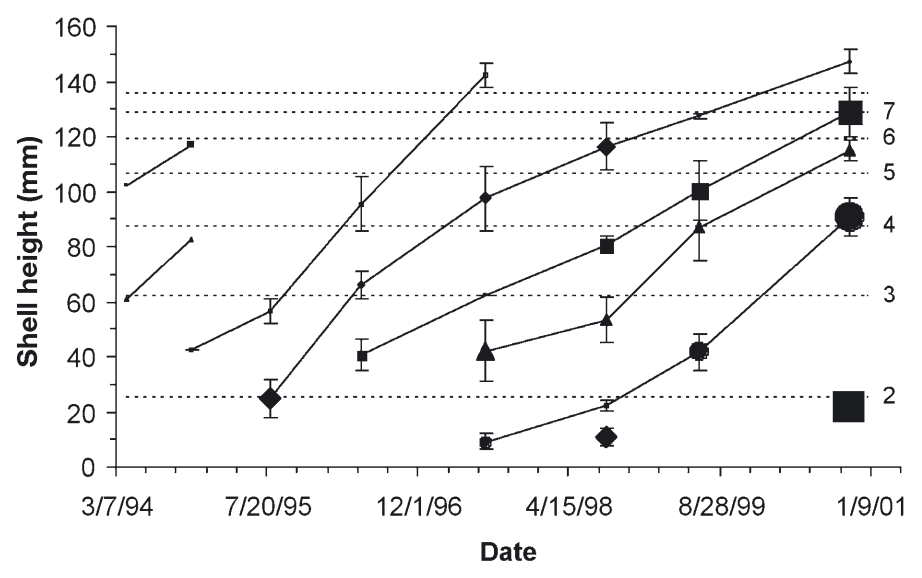

Fig. 2. Placopecten magellanicus. Growth of scallop cohorts at Site 17, which was closed to all bottom fishing in January 1995. The linear size of the symbols are proportional to relative abundance; error bars are standard deviations estimated with NORMSEP. Broken horizontal lines are the expected sizes at age of Georges Bank scallops (Serchuk et al. 1982). Dates given as mo/d/yr
Table 4. Placopecten magellanicus. Production (g ww $\mathrm{m}^{-2}$ $\mathrm{yr}^{-1}$ ) at Site 17 estimated by 3 methods

\begin{tabular}{|c|c|c|c|}
\hline Year & $\begin{array}{l}\text { Increment- } \\
\text { summation }\end{array}$ & $\begin{array}{l}\text { Method - } \\
\text { Size- } \\
\text { frequency }\end{array}$ & P:B ratio \\
\hline 1994 & 23 & a & 3 \\
\hline 1995 & 18 & 11 & 8 \\
\hline 1996 & 40 & 16 & 16 \\
\hline 1997 & 52 & 72 & 101 \\
\hline 1998 & 83 & 210 & 276 \\
\hline 1999 & 171 & 172 & 207 \\
\hline 2000 & 223 & 422 & 684 \\
\hline
\end{tabular}

to generate a length-frequency distribution (Table 2). Many of the regression coefficients, $b$, were close to 3, indicating that growth of the selected part measured was nearly isometric with weight (Table 2). Values $>3$ indicated that growth was allometric, such that weight increased proportionately faster than the part or structure of the animal measured.

We calculated production indirectly for 19 additional species (Table 3); P:B values estimated with Brey's relationship (Brey 2001) varied between some sites because of differences in mean individual biomass between sites (Table 3).

At Site 17, individual scallop cohorts were identified and followed over the sampling years; the 1994 cohort could be tracked until 2000 (Fig. 2). Scallop numbers were low in 1994 but increased following the closure of this area in 1995. Estimated cohort numbers fluctuated among cruises, but the modal shell heights are consistent with published growth curves for Georges Bank scallops (Serchuk et al. 1982). Scallop production at Site 17 began to increase in 1996 and reached its highest level in 2000 (Table 4). Production estimates from the increment-summation method are similar in magnitude and trend to those estimated with the sizefrequency method and Brey's (2001) empirical model. The lower production estimates for the incrementsummation method in 1998 and 2000 can be explained by the presence of cohorts in those years that were not associated with growth increments (Fig. 2). The large age- 1 cohort in 1998 and age- 2 cohort in 2000 were identified only once, and therefore did not contribute to the increment-summation production estimates. In contrast, the size-frequency method and Brey's model are based on the biomass sampled in those years, including all the cohorts.

The sum of the biomass $\left(\mathrm{g} \mathrm{ww} \mathrm{m}^{-2}\right.$ ) of the 39 species examined in this study varied considerably among some sites (Table 5). These estimates represent the sum of the biomass calculated from the size-frequency 
Table 5. Mean total biomass $\left(\mathrm{g} w \mathrm{w} \mathrm{m}^{-2}\right)$ at each site and year

\begin{tabular}{|c|c|c|c|c|c|c|c|c|c|}
\hline Site & Depth (m) & Disturbance & 1994 & 1995 & 1996 & 1997 & 1998 & 1999 & 2000 \\
\hline 16 & Shallow (62) & Disturbed & & & 3101 & & & & \\
\hline $17 \mathrm{~W}$ & Shallow (50) & Disturbed & & & & 61 & 77 & 476 & \\
\hline $17^{\mathrm{a}}$ & Shallow (47) & Disturbed & 51 & & & & & & \\
\hline $18^{\mathrm{a}}$ & Shallow (48) & Disturbed & & 91 & 135 & 189 & 132 & 136 & 196 \\
\hline $18^{\mathrm{a}}$ & Shallow (48) & Undisturbed & 123 & & & & & & \\
\hline $17^{\mathrm{a}}$ & Shallow (47) & Undisturbed & & 129 & 121 & 509 & 1301 & 1180 & 2474 \\
\hline $17 \mathrm{~S}$ & Shallow (50) & Undisturbed & & & & 592 & & 277 & \\
\hline 13 & Deep (80) & Disturbed & 212 & & & 162 & 246 & 108 & \\
\hline 10 & Deep (90) & Undisturbed & 374 & & & & & & \\
\hline 11 & Deep (85) & Undisturbed & 508 & & & & & & \\
\hline 20 & Deep (85) & Undisturbed & 299 & & & 532 & 1073 & 535 & \\
\hline
\end{tabular}

method and from the samples when production was calculated indirectly. Biomass $\left(\mathrm{g} w \mathrm{w} \mathrm{m}^{-2}\right.$ ) ranged from 50 to 3101 , with a mean of 513 . The highest biomass estimate, $3101 \mathrm{~g} \mathrm{ww} \mathrm{m}^{-2}$, was from Site 16 in 1996, where we encountered dense aggregations of Atlantic sea scallops Placopecten magellanicus. At Site 17, benthic megafaunal biomass increased by 2 orders of magnitude from $51 \mathrm{~g} \mathrm{ww} \mathrm{m}^{-2}$ in 1994 to $2474 \mathrm{~g} \mathrm{ww} \mathrm{m}^{-2}$ in 2000. In contrast, biomass estimates from 1994 to 2000 varied comparatively little at disturbed Site 18, with a maximum of $196 \mathrm{~g} \mathrm{ww} \mathrm{m}^{-2}$ in 2000 . The order of magnitude increase in biomass at Site $17 \mathrm{~W}$ from $77 \mathrm{~g} \mathrm{ww}$ $\mathrm{m}^{-2}$ in 1998 to $476 \mathrm{~g} \mathrm{ww} \mathrm{m}^{-2}$ in 1999 was largely due to an approximately 7 -fold increase in the biomass of $P$. magellanicus and a 4 -fold increase in the biomass of Strongylocentrotus droebachiensis. At the deep sites, mean biomass was consistently higher at the undisturbed sites for all 4 of the years we sampled. The 2-fold increase in biomass at Site 20 in 1998 was the result of a particularly dense aggregation of sea stars Asterias vulgaris in the single replicate we were able to obtain at that station in 1998.

Because biomass-to-energy conversions are very different across taxa, we converted production from $\mathrm{g}$ ww $\mathrm{m}^{-2} \mathrm{yr}^{-1}$ to $\mathrm{kcal} \mathrm{m} \mathrm{m}^{-2} \mathrm{yr}^{-1}$ using taxon-specific conversions from Brey (2001) for each site and year. By doing this, we were able to account for the influence of community composition on estimates of production in energy units across sites and years. Production $\left(\mathrm{kcal} \mathrm{m}^{-2}\right.$ $\mathrm{yr}^{-1}$ ) at the shallow sites followed a pattern similar to biomass $\left(\mathrm{g} w \mathrm{w} \mathrm{m}^{-2}\right)$, with production increasing from $17 \mathrm{kcal} \mathrm{m}^{-2} \mathrm{yr}^{-1}$ in 1994 to $215 \mathrm{kcal} \mathrm{m}^{-2} \mathrm{yr}^{-1}$ in 2000 (Fig. 3). However, the increase at Site 17 in energy units was only 12-fold, considerably less than the nearly 49-fold increase in biomass $\left(\mathrm{g} \mathrm{ww} \mathrm{m}^{-2}\right.$ ) over that period.

To examine the contribution of some important taxa to the production of 3 shallow sites, we isolated the 4 species that contributed most to total production at undisturbed Site 17, disturbed Site 17W, and disturbed
Site 18 (Fig. 4). Asterias vulgaris accounted for a significant proportion of the production in most years at all 3 sites. At Site 17, the contribution to production of the sea urchin Strongylocentrotus droebachiensis and sea scallop Placopecten magellanicus significantly increased after 1996. These 2 species are primarily responsible for the increases in production inside Closed Area II at Site 17 from 1997 to 2000. A scavenging omnivorous crab Cancer irroratus was also responsible for a significant proportion of the production at Site 18 from 1994 to 2000. C. irroratus represented only a small proportion of the production at Sites 17 and $17 \mathrm{~W}$.

At the deep sites, production ( $\mathrm{kcal} \mathrm{m}^{-2} \mathrm{yr}^{-1}$ ) was significantly higher at undisturbed Site 20 than at the deep, disturbed Site 13 for the 4 years sampled (2-tailed F-test for homogeneity of variances, p > 0.05; paired $t$-test, $\mathrm{p}=0.003$ ) (Fig. 5). Two species, the tubebuilding worm Thelepus cincinnatus, along with Asterias vulgaris, constituted a significant fraction of the production at undisturbed Site 20 (Fig. 6) for all 4 years sampled. T. cincinattus was comparatively absent at

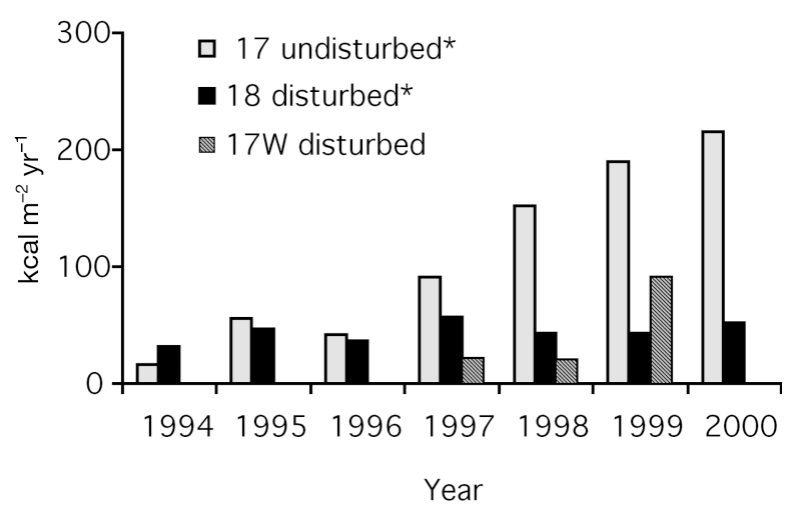

Fig. 3. Production $\left(\mathrm{kcal} \mathrm{m}^{-2} \mathrm{yr}^{-1}\right)$ for shallow Sites $17,17 \mathrm{~W}$ and 18 from 1994 to 2000 . ${ }^{*}$ Prior to the area closure in 1995, Site 17 was disturbed and Site 18 undisturbed 


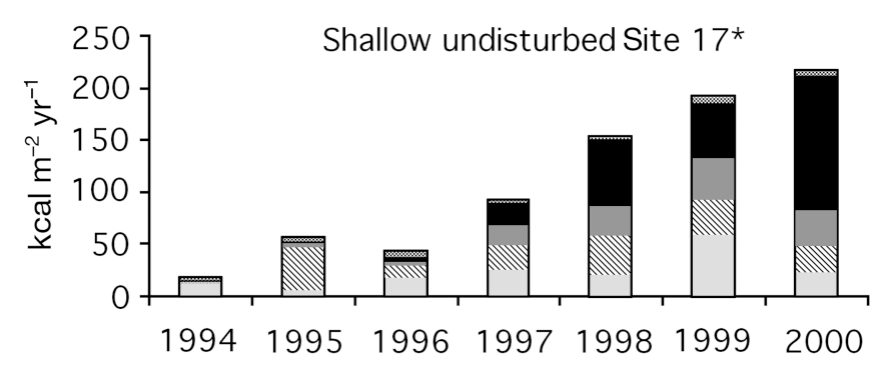

Shallow disturbed Site 17W
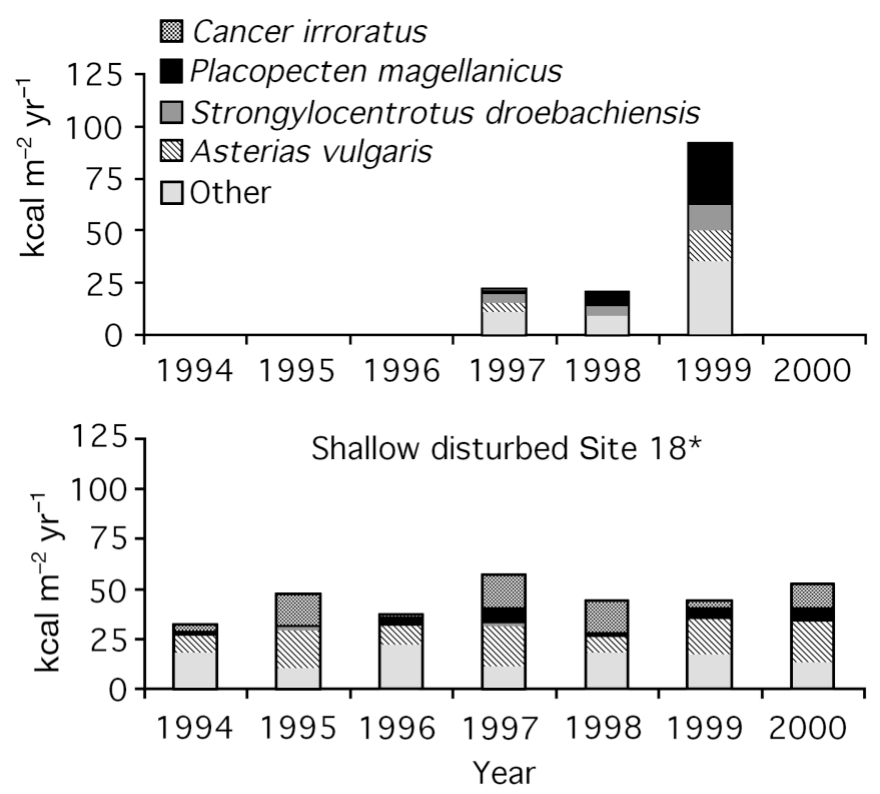

Fig. 4. Production $\left(\mathrm{kcal} \mathrm{m}^{-2} \mathrm{yr}^{-1}\right)$ for shallow Sites $17,17 \mathrm{~W}$ and 18 from 1994 to 2000, with several important species highlighted. * Prior to the area closure in 1995 Site 17 was disturbed and Site 18 undisturbed

deep, disturbed Site 13. There, the bivalve mollusc Placopecten magellanicus, along with 5 species of the genus Astarte and the sea star A. vulgaris, represented the bulk of the production.

Community $\mathrm{P}: \mathrm{B}$ ratios for each site and year ranged from 0.26 to 0.91 . At the shallow sites, $\mathrm{P}: \mathrm{B}\left(\mathrm{yr}^{-1}\right)$ remained comparatively static at disturbed Site 18 , with fluctuations of less than $17 \%$ from the $7 \mathrm{yr}$ mean, save in 1995 when the P:B was $38 \%$ higher than the mean (Fig. 7a). At Site 17, P:B followed a downward trend over the study to 0.26 in 2000 , approximately one-third of the peak at that station of 0.75 in 1995. Turnover rates at the deep sites varied, with no significant difference between the 2 sites for the 4 years both sites were sampled ( $t$-test, $\mathrm{p}=0.48$ ) (Fig. $7 \mathrm{~b}$ ). The low turnover rate of 0.35 at Site 20 in 1998 was primarily the result of a dense aggregation of particularly large Asterias vulgaris.

\section{DISCUSSION}

We have documented a steady and marked increase in the production of the benthic megafauna inside an area closed to all mobile fishing gear disturbance compared to the same area prior to the closure and to an area outside the closure where fishing continued (Fig. 3). At deep sites on the Canadian side of Georges Bank, we have documented significantly higher production in an unfished area versus an area that experienced chronic disturbance by bottom-towed fishing gear (Fig. 5). Although we were not able to obtain estimates of variance, which would have allowed for direct between-site comparisons of production, the increase in production at the shallow Site 17 and the markedly higher production at the deep undisturbed site versus the disturbed site yield an obvious pattern of lower production at sites subjected to chronic fishing disturbance.

We aimed to estimate production directly from the communities we sampled to the extent possible, although there are some well-documented drawbacks of the size-frequency method employed for this study (Morin et al. 1987). When cohorts are identifiable, the increment-summation method is preferable because it avoids some of the strong assumptions of the sizefrequency method. For Placopecten magellanicus at Site 17 , we obtained good agreement between the 3 methods of production estimation. With the increment summation method, there are potential errors in attributing scallops to correct cohorts. However, the influence of these ageing errors is limited, because a given scallop can only contribute to the production of one cohort or another. The agreement between the methods increases our confidence in the sizefrequency production estimates that were made for the bulk of the species and the use of Brey's method for the remaining species.

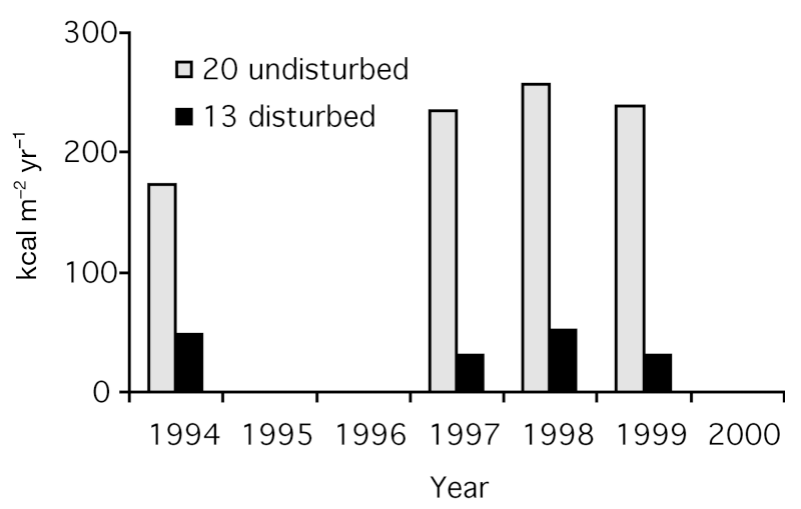

Fig. 5. Production $\left(\mathrm{kcal} \mathrm{m}^{-2} \mathrm{yr}^{-1}\right)$ for deep Sites 13 and 20 for 1994 and 1997 to 1999 
As with other studies, a small proportion of the species examined in this study constituted the bulk of the biomass and production (Warwick 1980, Kenchington et al. 2001). In a 3 yr study of the effects of trawling on the Grand Banks, $95 \%$ of the biomass was accounted for by 23 species (Kenchington et al. 2001). A single or small number of species can be responsible for an overwhelming proportion of the production in suspension-feeding communities (Warwick 1980). In a study of the benthic production of the Bay of Fundy, an active suspension feeder, the horse mussel Modiolus modiolus, accounted for the bulk of production (Wildish \& Peer 1983). In this study, a passive suspension feeder, Placopecten magellanicus, accounted for a large proportion of the production at the shallow recovering Site 17 (Fig. 4). Although the feeding method of Thelepus cincinnatus was not examined in this study, a congener, T. crispus, has been observed to suspensionfeed (Musgrove 1983). At the deep undisturbed sites, T. cincinnatus dominated production (Fig. 6).

Our estimates of benthic megafaunal biomass fall within the range of 1 to $5272 \mathrm{~g} \mathrm{ww} \mathrm{m}^{-2}$ for 2 extensive benthic surveys of Georges Bank benthos conducted from 1956 to 1965 and in 1977 (Steimle 1987) (Table 5). In those studies, estimates are for benthos retained on a 1 and $0.5 \mathrm{~mm}$ sieve, and preserved in formaldehyde and alcohol, respectively. The mean biomass we calculated, $513 \mathrm{~g} \mathrm{ww} \mathrm{m}^{-2}$, is substantially higher than the
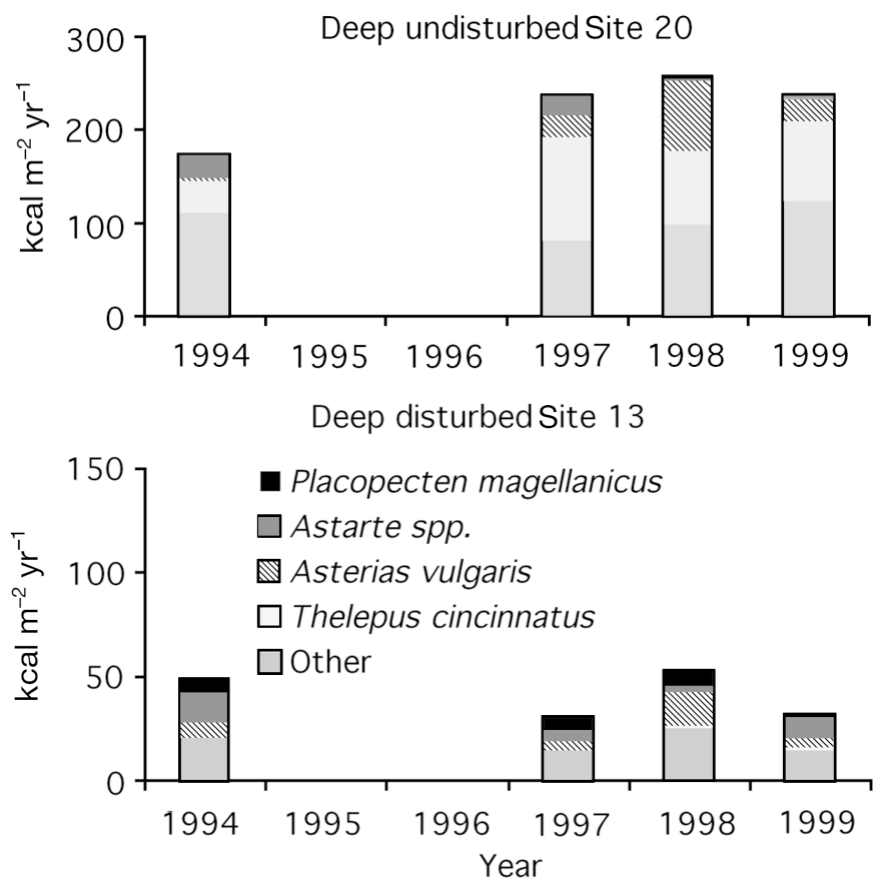

Fig. 6. Production $\left(\mathrm{kcal} \mathrm{m}^{-2} \mathrm{yr}^{-1}\right)$ for deep Sites 20 and 13 from 1994 and 1997 to 1999, with several important taxa highlighted. Note the change in scale
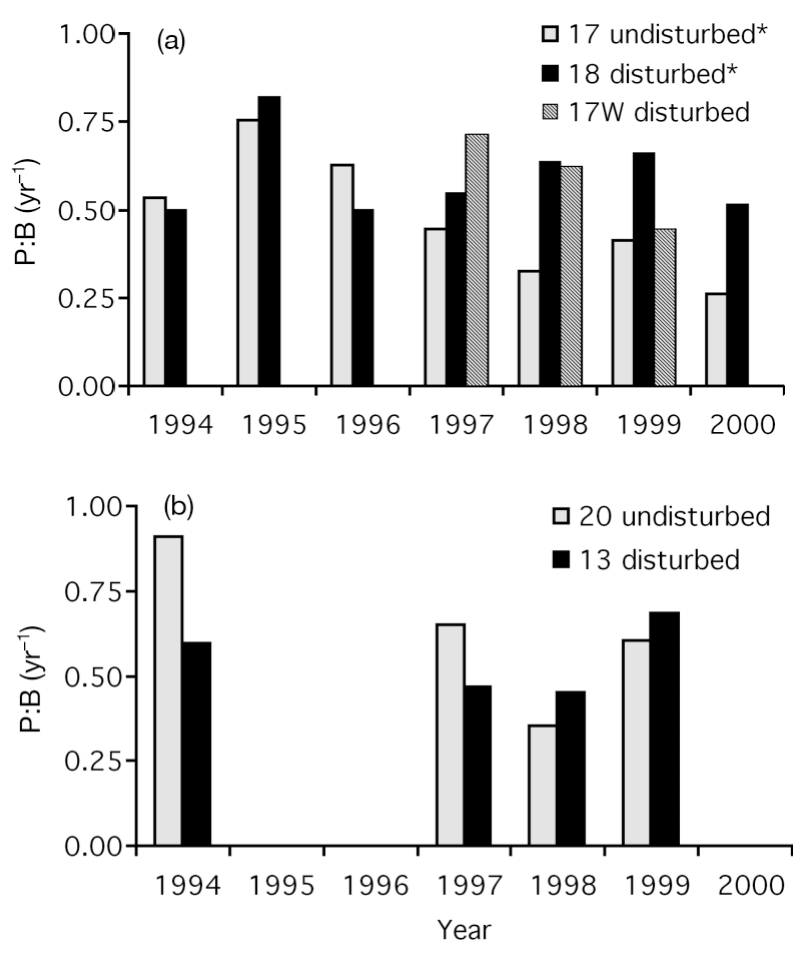

Fig. 7. (a) P:B ratios $\left(\mathrm{yr}^{-1}\right)$ for shallow Sites 17, 17W, and 18 from 1994 to 2000, (b) P:B ratios ( $\mathrm{yr}^{-1}$ ) for deep Sites 13 and 20 from 1994 and 1997 to $1999 .{ }^{*}$ Prior to the area closure in 1995 , Site 17 was disturbed and Site 18 undisturbed

mean biomass reported in both of the earlier studies (239 $\mathrm{g} \mathrm{ww} \mathrm{m}^{-2}$ in 1956 to $1965,313 \mathrm{~g} \mathrm{ww} \mathrm{m}^{-2}$ in 1977) (Steimle 1987). We focused our sampling on the relatively productive gravel pavement areas of the northern part of Georges Bank, where Placopecten magellanicus dominates the benthic biomass (Fig. 1). Our estimates are likely not representative of the whole of Georges Bank as a result. Our values also bound the mean estimates for both Browns Bank and the Bay of Fundy of 64 and $199 \mathrm{~g} \mathrm{ww} \mathrm{m}^{-2}$, respectively (Wildish \& Peer 1983, Wildish et al. 1989). Estimated scallop biomass at Site 17 in this study increased by approximately $200 \times\left(10 \mathrm{~g} \mathrm{~m}^{-2}\right.$ in 1994 and $2075 \mathrm{~g} \mathrm{~m}^{-2}$ in 2000), a much higher rate than the 9- to 14 -fold increase reported for all 3 of the closed areas on Georges Bank and the Nantucket Lightship combined (Murawski et al. 2000). This difference is likely due to our relatively small sampling effort combined with our targeting of prime scallop habitat.

Conversion of ww production to energy units allowed for a more meaningful comparison of the trophic dynamics of different sites sampled within this study and to past studies of Georges Bank. Although ww production was estimated to be nearly $50 \%$ higher at Site 17 than at Site 20 in 1999 (489 and $324 \mathrm{~g} \mathrm{ww} \mathrm{m}^{-2}$ 
$\mathrm{yr}^{-1}$, respectively), we found production in $\mathrm{kcal} \mathrm{m}^{-2} \mathrm{yr}^{-1}$ to be considerably higher at Site 20 than at Site 17 (238 and $190 \mathrm{kcal} \mathrm{m}^{-2} \mathrm{yr}^{-1}$, respectively). This is a result of the species that dominated the very different communities at these sites; at Site 17, production was dominated by the bivalve Placopecten magellanicus and the echinoderm Strongylocentrotus droebachiensis versus the proportionately higher-energy-yielding Thelepus cincinnatus and Asterias vulgaris at Site 20.

The downward trend in the P:B ratios at the recovering Site 17 is consistent with the findings of other studies (Warwick 1980). The P:B of a population decreases with mean age, resulting in changes in annual P:B if the age composition of a population changes. These changes can result from natural fluctuations in year class strength and/or changes in exploitation. It follows that as the mean age of a dominant species increases, community P:B decreases (Warwick 1980). Community P:B inside Site 17 in 2000 was 0.26 , approximately onethird of the peak of 0.75 observed in 1995 .

A similar phenomenon has been observed in the North Sea, where infaunal P:B increased with increasing benthic disturbance (Jennings et al. 2001). This observed increase in infaunal production per unit biomass could not compensate for the loss in biomass and thus infaunal production decreased at the most disturbed sites (Jennings et al. 2001). We found a similar trend in this study: although P:B decreased at undisturbed Site 17 over the $7 \mathrm{yr}$, the increase in biomass at Site 17 contributed to production levels that were several-fold higher than at the disturbed Site 18. In contrast, the community $\mathrm{P}: \mathrm{B}$ ratios at our deep sites showed no sign of a trend in relation to disturbance (Fig. 7b). The hypothesis of higher turnover rates with increasing disturbance was not evident at these deep sites.

The marked increase in production at shallow Site 17 is most likely related to the closure and associated cessation of mobile fishing gear disturbance that occurred in early 1995. Prior to the cessation of scallop dredging and fish trawling, production at Site 17 was approximately half of the level at Site 18 (Fig. 3). After the closure, production at Site 17 increased to approximately $4 \times$ the level at Site 18, mainly due to an increase in the population of Placopecten magellanicus (Fig. 4). To see if the difference was solely due to scallops, we examined the production of Sites 17 and 18 with the sea scallop production removed. Production, with sea scallops removed, at the recovering site averaged $102 \mathrm{kcal}$ $\mathrm{m}^{-2} \mathrm{yr}^{-1}$ from 1998 to 2000, over twice as high as the average of $41 \mathrm{kcal} \mathrm{m}^{-2} \mathrm{yr}^{-1}$ for the same period at Site 18. Therefore, the difference in production estimates was not solely due to an increase in scallop abundance. Along with Strongylocentrotus droebachiensis and Asterias vulgaris, the gastropod Buccinum undatum represented a large proportion of the production inside the closed area.

Unlike the shallow sites, the community composition at the deep sites seemed to be quite altered by disturbance. The soft-bodied, tube-building, terebellid polychaete Thelepus cincinnatus, although present, made only a small contribution to the production in the disturbed area while accounting for 20 to $47 \%$ of the production at Site 20 (Fig. 6). Bivalve molluscs, including Placopecten magellanicus and Astarte spp., constituted a relatively high proportion of the production at the disturbed sites, most likely due to their ability to survive in the wake of a scallop dredge or fish trawl. The relative dearth of $P$. magellanicus at the undisturbed sites may be related to differential settling success in areas of abundant epifaunal cover. Analyses of photographs of the bottom at these sites have indicated that percent cover of the calcareous tube-building worm Filograna implexa, as well as plant-like animals such as bryozoans, was significantly higher at Site 20 than at Site 13 (Collie et al. 2000).

The decrease in benthic production associated with disturbance by mobile fishing gear is inextricably related to sediment type and probably cannot be generalized to other sediment types and communities. Our results are in agreement with the predictions of Jennings et al. (2001) that gravel sediment, which supports a diverse array of biogenic habitat, may be particularly vulnerable to the type of disturbance associated with scallop dredging and fish trawling. Biogenic habitatFilograna implexa colonies, bryozoa, and hydroids supports many invertebrate benthic taxa including polychaetes, brittle stars, and shrimps (Collie et al. 1997). Reefs of the tube-building worm Sabellaria in the Bristol Channel add structural complexity to the hard-bottom habitat on which they grow (George \& Warwick 1985). A large number of small species were found within the complex biogenic habitat the reef creates (George \& Warwick 1985).

That our samples only account for a large size fraction within the macrofauna, and skip over the meiofauna entirely, would likely not significantly alter our conclusions. A size-based model of the effects of bottom trawling on the benthic community in the North Sea predicted that smaller meiofauna would be little affected by trawling disturbance (Duplisea et al. 2002). Experiments in the southern North Sea support these predictions, as trawling had no effect on the biomass of the meiofaunal community (Schratzberger et al. 2002). Meiofauna generally have higher turnover rates and suffer lower mortality in the path of bottom-fishing towed gear than macrofauna. More importantly, macrofauna play a much more significant role in the diets of commercially important fish than meiofauna. 
Many of the species that contributed significantly to the production estimates in this study are prey of commercially important fish on Georges Bank. Atlantic cod Gadus morhua on Georges Bank prey on several of the species and/or taxonomic categories included in this study, including Dichelopandalus leptocerus, Crangon septemspinosa, Cancer irroratus, Pagurus spp., and Hyas spp. Haddock Melanogrammus aeglefinus on Georges Bank prey on bivalve molluscs, polychaete worms, and the brittle star Ophiopholis aculeata (Bowman et al. 2000).

We have recorded both significantly lower levels of production at disturbed sites and a significant increase in production after the cessation of mobile fishing gear disturbance at shallow sites. Sediment type is an important variable when gauging the effects of bottom-fishing towed-gear disturbance. The effect of such gear on the benthic production on the gravel pavement of Georges Bank is conspicuous. Cessation of disturbance by bottom-fishing towed gear has allowed for a marked increase in the productivity of the benthos in areas of prior heavy fishing disturbance. In areas with no history of disturbance, production is markedly higher than in areas that are chronically fished.

Our findings will potentially assist fishery managers when considering area closures and the use of lowimpact bottom-fishing towed gear as fishery management tools. We have determined that some bottomfishing towed gear may have a large detrimental effect on an ecosystem service provided by benthic megafauna, the transfer of primary production to higher trophic levels. Because benthic megafaunal production in the Georges Bank ecosystem may have a significant effect on fisheries production, the effects of fishing gear that lower benthic megafaunal production should be taken into account in an ecosystem-based management regime.

Acknowledgements. This work was supported by NOAA Cooperative Marine Education and Research Program (Award no. NA87FE0527), by the US Geological Survey (Cooperative Research Agreement 1434-HQ-96-AG-01533), the National Undersea Research Center (Award no. PS219199), and Rhode Island Sea Grant (Award no. NAO7RG0363). J.M.H. was partially supported by the Joshua MacMillan Fellowship. We thank David Taylor for assisting with the body size measurements and Allison DeLong for assistance with the data analysis. Michel Kaiser, Allison DeLong, Heike Lotze and 2 anonymous reviewers made valuable comments that contributed significantly to the improvement of the manuscript.

\section{LITERATURE CITED}

Auster PJ, Langton RW (1999) The effects of fishing on fish habitat. In: Benaka L (ed) Fish habitat: essential fish habi- tat and rehabilitation. American Fisheries Society, Bethesda, MD, p 150-187

Bigford TE (1979) Synopsis on the biology of the rock crab, Cancer irroratus Say. NOAA Tech Rep NMFS Circ 426

Bowman RE, Stillwell CE, Michaels WL, Grosslein MD (2000) Food of northwest Atlantic fishes and 2 common species of squid. NOAA Tech Memo NMFS 155

Bradstock M, Gordon DP (1983) Coral-like bryozoan growths in Tasman Bay and their protection to conserve commercial fish stocks. NZ J Mar Freshw Res 17:159-163

Brey T (2001) Population dynamics in benthic invertebrates: a virtual handbook. Version 01.2. http://www.awibremerhaven.de/Benthic/Ecosystem/FoodWeb/Handbook/ main.html. Alfred Wegener Institute for Polar and Marine Research, Bremerhaven

Collie JS (1985) Life history and production of three amphipod species on Georges Bank. Mar Ecol Prog Ser 22: 229-238

Collie JS (1987) Food consumption by yellowtail flounder in relation to production of its benthic prey. Mar Ecol Prog Ser 36:205-213

Collie JS, Escanero GS, Valentine PC (1997) Effects of bottom fishing on the benthic megafauna of Georges Bank. Mar Ecol Prog Ser 155:159-172

Collie JS, Escanero GS, Valentine PC (2000) Photographic evaluation of the impacts of bottom fishing on benthic epifauna. ICES J Mar Sci 57:987-1001

Crisp DJ (1984) Energy flow measurements. In: Holme NA, McIntyre AD (eds) Methods for the study of marine benthos. Blackwell Scientific Publications, Boston, MA, p 284-372

Dayton PK, Hessler RR (1972) Role of biological disturbance in the deep sea. Deep-Sea Res 19:199-208

Duplisea DE, Jennings S, Warr KJ, Dinmore TA (2002) A sizebased model of bottom trawling on benthic community structure. Can J Fish Aquat Sci 59:1785-1795

Emerson CW (1989) Wind stress limitation of benthic secondary production in shallow, soft-sediment communities. Mar Ecol Prog Ser 53(1):65-77

Fogarty MJ, Murawski SA (1998) Large-scale disturbance and the structure of marine systems: fishery impacts on Georges Bank. Ecol Appl 8(1):S6-S22

George CL, Warwick RM (1985) Annual macrofauna production in a hard-bottom reef community. J Mar Biol Assoc UK 65:713-735

Giguère $M$, Brulotte $S$ (2000) Whelk in Québec coastal waters. DFO, Science, Stock Status Report C4-09. Department of Fisheries and Oceans, Quebec

Haefner PA (1979) Comparative review of the North Atlantic Caridean shrimps (Crangon), with emphasis on C. septemspinosa. Bull Biol Soc Wash 3:1-40

Hartnoll RG (1963) The biology of Manx spider crabs. Proc Zool Soc Lond 143(3):423-496

Hartnoll RG (1965) The biology of spider crabs: a comparison of British and Jamaican species. Crustaceana 9(1):1-16

Hasselblad V (1966) Estimation of parameters for a mixture of normal distributions. Technometrics 8:431-444

Howe S, Leathem W (1984) Secondary production of benthic macrofauna at three stations of Delaware Bay and Coastal Delaware. NOAA Tech Memo NMFS-NEFC-32

Jennings S (2000) Patterns and prediction of population recovery in marine reserves. Rev Fish Biol Fish 10(2): 209-231.

Jennings S, Dinmore TA, Duplisea DD, Warr KJ, Lancaster JE (2001) Trawling disturbance can modify benthic production processes. J Anim Ecol 70:459-475

Jennings S, Nicholson MD, Dinmore TA, Lancaster JE (2002) 
Effects of chronic trawling disturbance on the production of infaunal communities. Mar Ecol Prog Ser 243:251-260

Kaiser MJ, Spencer BE (1996) The effects of beam trawl disturbance on infaunal communities in different habitats. J Anim Ecol 65:348-358

Kaiser MJ, Collie JS, Hall SJ, Jennings S, Poiner IR (2002) Modification of marine habitats by trawling activities: prognosis and solutions. Fish Fish Ser 3:114-136

Kenchington ELR, Prena J, Gilkinson KD, Gordon DC and 6 others (2001) Effects of experimental otter trawling on the macrofauna of a sandy bottom ecosystem on the Grand Banks of Newfoundland. Can J Fish Aquat Sci 58: 1043-1057

Kristensen E (1984) Life cycle, growth and production in estuarine populations of the polychaetes Nereis virens and Nereis diversicolor. Holarct Ecol 7(3):249-256

Krueger CC, Martin FB (1980) Computation of confidence intervals for the size-frequency (Hynes) method of estimating secondary production. Limnol Oceanogr 25(4):773-777

Langton RW, Steneck RS, Gotceitas V, Juanes F, Lawton P (1996) The interface between fisheries research and habitat management. N Am J Fish Manag 16(1):1-7

Lough RG, Valentine PC, Potter DC, Auditore PJ, Bolz GR, Neilson JD, Perry RI (1989) Ecology and distribution of juvenile cod and haddock in relation to sediment type and bottom currents on eastern Georges Bank. Mar Ecol Prog Ser 56:1-12

McClanahan TR, Arthur R (2001) The effect of marine reserves and habitat on populations of East African coral reef fishes. Ecol Appl 11(2):559-569

Morin A, Mousseau TA, Roff DA (1987) Accuracy and precision of secondary production estimates. Limnol Oceanogr 32(6):1342-1352

Murawski SA, Brown R, Lai H-L, Rago PJ, Hendrickson L (2000) Large-scale closed areas as a fishery-management tool in temperate marine systems: the Georges Bank experience. Bull Mar Sci 66(3):775-798

Musgrove N (1983) The feeding behavior of the terebellid polychaete Thelepus crispus Johnson in response to currents. J Shellfish Res 3(1):113

Pienaar LV, Ricker WE (1966) Estimating mean weight from length statistics. J Fish Res Board Can 25:2743-2747

Editorial responsibility: Kenneth Sherman (Contributing Editor), Narragansett, Rhode Island, USA
Rago P, McSherry M (2001) Spatial distribution of fishing effort for sea scallops: 1998-2000. In: Workshop on effects of fishing gear on fish habitat in the northeastern US. Northeast Fisheries Science Center Reference Document 02-01, Appendix G, Woods Hole, MA

Roberts CM, Bohnsack JA, Gell F, Hawkins JP, Goodridge R (2001) Effects of marine reserves on adjacent fisheries. Science 294(5548):1920-1923

Robertson AI (1979) The relationship between annual production:biomass ratios and lifespans for marine macrobenthos. Oecologia 38:193-202

Schratzberger M, Dinmore TA, Jennings S (2002) Impacts of trawling on the diversity, biomass and structure of meiofauna assemblages. Mar Biol 140(1):83-93

Serchuk FM, Wood PW, Rak RS (1982) Review and assessment of the Georges Bank, Mid-Atlantic and Gulf of Maine Atlantic sea scallop (Placopecten magellanicus) resources. National Marine Fisheries Service, Woods Hole, MA Lab Ref Doc 82--06

Steimle FW (1987) Production by the benthic fauna. In: Backus RH (ed) Georges Bank. MIT Press, Cambridge, MA, p 310-314

Valentine PC, Lough RG (1991) The sea floor environment and the fishery of eastern Georges Bank: the influence of geologic and oceanographic environmental factors on the abundance and distribution of fisheries resources of the northeastern United States continental shelf. Open-File Rep 91-439, Dept Interior, US Geological Survey, Woods Hole, MA

Warwick RM (1980) Population dynamics and secondary production of benthos. In: Tenore KR, Coull BC (eds) Marine benthic dynamics. University of South Carolina Press, Columbia, SC, p 1-24

Wildish DJ, Wilson AJ, Frost B (1989) Benthic macrofaunal production of Browns Bank, northwest Atlantic. Can J Fish Aquat Sci 46:584-590

Wildish DJ, Peer D (1983) Tidal current speed and production of benthic macrofauna in the lower Bay of Fundy. Can J Fish Aquat Sci 40(Suppl 1):309-321

Williams AB (1984) Shrimps, lobsters, and crabs of the Atlantic coast of the eastern United States, Maine to Florida. Smithsonian Institution Press, Washington, DC

Submitted: August 14, 2002; Accepted: April 30, 2003 Proofs received from author(s): September 16, 2003 